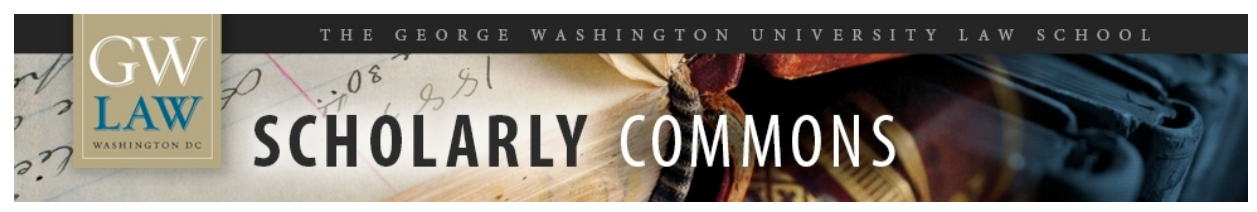

\title{
How Justice Thomas Determines the Original Meaning of Article li of the Constitution
}

\author{
Gregory E. Maggs \\ George Washington University Law School, gmaggs@law.gwu.edu
}

Follow this and additional works at: https://scholarship.law.gwu.edu/faculty_publications

Part of the Law Commons

\section{Recommended Citation}

Maggs, Gregory E., How Justice Thomas Determines the Original Meaning of Article li of the Constitution (2017). Gregory E. Maggs, How Justice Thomas Determines the Original Meaning of Article II of the Constitution, 127 Yale L.J. F. 210 (2017) http://www.yalelawjournal.org/forum/how-justice-thomasdetermines-the-original-meaning-of-article-ii-of-the-constitution; GWU Law School Public Law Research Paper No. 2017-60; GWU Legal Studies Research Paper No. 2017-60. Available at SSRN: http://ssrn.com/ abstract $=3024280$

This Article is brought to you for free and open access by the Faculty Scholarship at Scholarly Commons. It has been accepted for inclusion in GW Law Faculty Publications \& Other Works by an authorized administrator of Scholarly Commons. For more information, please contact spagel@law.gwu.edu. 
THE YALE LAW JOURNAL FORUM

AUGUST 2, 2017

\title{
How Justice Thomas Determines the Original Meaning of Article II of the Constitution
}

\author{
Gregory E. Maggs
}

\section{INTRODUCTION}

The scope of the President's powers under Article II of the Constitution has been a key topic during much of Justice Thomas's twenty-five years on the Supreme Court. The attacks of September 11, 2001, for instance, prompted military responses testing the inherent constitutional authority of the President and the extent to which other branches can limit this authority. ${ }^{1}$ Accordingly, no discussion of Justice Thomas's jurisprudence over the past quarter century would be complete without a thorough understanding of how he approaches Article II questions.

Justice Thomas has a well-known reputation for striving to decide constitutional issues in accordance with the original meaning of the Constitution. ${ }^{2}$ This Essay concerns a specific question about this methodology in cases concerning presidential powers: How does Justice Thomas determine the original meaning of Article II of the U.S. Constitution? The answer to this question has both academic and practical dimensions. The principal academic concerns are whether Justice Thomas's approach is complete and logical and whether it accords with

1. See, e.g., Hamdan v. Rumsfeld, 548 U.S. 557 (2006) (addressing the President's inherent constitutional power to establish military tribunals to try enemy combatants for war crimes defined by the President); Hamdi v. Rumsfeld, 542 U.S. 507 (2004) (considering the President's authority to detain suspected enemy combatants without bringing them before a federal judge or neutral tribunal).

2. See generally Gregory E. Maggs, Which Original Meaning of the Constitution Matters to Justice Thomas?, 4 N.Y.U. J.L. \& LIBERTY 494 (2009) (discussing Justice Thomas's originalism). 
his approach in other constitutional issues. The answer is practical because it reveals what kinds of arguments and sources persuade Justice Thomas.

In this Essay, I seek to answer the question of how Justice Thomas determines the original meaning of Article II by making three observations based on opinions authored or joined by Justice Thomas. The Essay proceeds in two Parts. Part I discusses Justice Thomas's typical approach to constitutional issues. Part II then notes how his approach differs in Article II cases.

\section{HOW JUSTICE THOMAS GENERALLY DECIDES CONSTITUTIONAL ISSUES}

Justice Thomas has made clear that he generally strives to decide constitutional questions in accordance with either the original meaning of the Constitution or Supreme Court precedent. ${ }^{3}$ While much could be written on Justice Thomas's views on precedent and stare decisis, ${ }^{4}$ my focus in this Essay is on his approach to original meaning. In recent cases, Justice Thomas has indicated that he looks for the original objective meaning of the Constitution and its amendments, as opposed to the original intent of the Framers who drafted them or the original understanding of the persons who voted to ratify them. ${ }^{5}$ For example, in his concurrence in part and concurrence in the judgment in McDonald $v$. City of Chicago, ${ }^{6}$ the decision that incorporated the Second Amendment against the states, Justice Thomas said: "When interpreting constitutional text, the goal is to discern the most likely public understanding of a particular provision at the time it was adopted."

Justice Thomas, however, does not limit his inquiry solely to evidence most demonstrative of the original objective meaning. On the contrary, Justice Thomas typically confirms this meaning by looking at a variety of sources more indicative of the original intent and original understanding. For example, he has cited the notes from the Constitutional Convention and the legislative his-

3. See, e.g., Rothgery v. Gillespie County, 554 U.S. 191, 218 (2008) (Thomas, J., dissenting) ("Because the Court's holding is not supported by the original meaning of the Sixth Amendment or any reasonable interpretation of our precedents, I respectfully dissent.").

4. See, e.g., John Eastman, Reflections on Justice Thomas's Twenty Years on the Bench, 88 U. DET. Mercy L. ReV. 691, 704 (2011) (comparing Justice Thomas's and Justice Scalia's treatments of precedent).

5. In recent years, judges and scholars have recognized that the Constitution may have more than one original meaning, depending on how the term is defined. See Maggs, supra note 2, at 496-500.

6. 561 U.S. 742 (2010).

7. Id. at 828 (Thomas, J., concurring in part and concurring in the judgment). 
tory of constitutional amendments, even though these sources typically provide better evidence of the original intent than of the original objective meaning. ${ }^{8}$ Similarly, he has cited the Federalist Papers and the records of the state ratifying conventions, even though these sources supply stronger evidence of the original understanding. ${ }^{9}$ Justice Thomas theorizes that citing these sources can confirm the original meaning. For instance, in McDonald, Justice Thomas cited some of the legislative history of the Fourteenth Amendment, explaining: "Statements by legislators can assist in this process [of determining the original public meaning] to the extent they demonstrate the manner in which the public used or understood a particular word or phrase."10

Finally, Justice Thomas tends to focus on the meaning of individual words and phrases in the Constitution, rather than on abstract constitutional principles. For instance, in his concurrence in United States $v$. Lopez, a case addressing whether Congress can regulate guns near schools under the Commerce Clause, Justice Thomas primarily sought to determine what, "[a]t the time the original Constitution was ratified, 'commerce' consisted of." ${ }^{11}$ Similarly, in his concurrence in part and concurrence in the judgment in Utah $v$. Evans, a case considering whether the federal government could use approximations in a decennial census, Justice Thomas asked what, "at the time of the [F] ounding," did the words "actual enumeration" mean?"

In these cases, as in most of his cases, he did not delve into purposes, economics, or political theories. He sought the definition of the words in the text of the Constitution. His general approach calls to mind a quotation by Antisthenes the Cynic, a Greek philosopher and proponent of Nominalism. Antisthenes was skeptical of abstractions as opposed to facts. "A horse I can see," Antisthenes said, "but horseness I cannot see."13

A variety of historical documents can provide evidence of the original meaning of Article II's provisions. Seven sources commonly cited by the Supreme Court include (1) the early state constitutions, ${ }^{14}$ (2) the Articles of Con-

8. See Maggs, supra note 2, at 509.

9. See id.; The Federalist Papers (Clinton Rossiter ed., 1961); The Debates in the Several State Conventions, on the Adoption of the Federal Constitution, As ReCommended by the General Convention at Philadelphia, in 1787 (Jonathan Elliot ed., 2d ed. 1891).

10. McDonald, 561 U.S. at 828 (Thomas, J., concurring in part and concurring in the judgment).

11. 514 U.S. 549, 585 (1995) (Thomas, J., concurring).

12. 536 U.S. 452, 493 (2002) (Thomas, J., concurring in part and concurring in judgment).

13. 8 Simplicius, Commentaria in Aristotelem 208 (Charles L. Kalbfleisch ed., 1907).

14. See, e.g., Hamdi v. Rumsfeld, 542 U.S. 507, 562 (Scalia, J., dissenting); Morrison v. Olson, 487 U.S. 654, 697 (1988) (Scalia, J., dissenting). 
federation, ${ }^{15}$ (3) the notes from the Constitutional Convention, ${ }^{16}(4)$ the Federalist Papers, ${ }^{17}(5)$ the records of the state ratifying conventions, ${ }^{18}(6)$ the records of early presidential practice, ${ }^{19}$ and (7) dictionaries from the Founding Era. $^{20}$

Early state constitutions are often helpful because several provisions in Article II are directly modeled after them. For example, the Massachusetts Constitution of 1780 made the Governor the "commander in chief of the army and navy" and gave him power to appoint judges and officers of the state. ${ }^{21}$ The Articles of Confederation also can provide guidance because the Constitution specifically rejected many of that document's flaws. ${ }^{22}$ In Freytag $v$. Commissioner, for instance, Justice Scalia considered the implications of moving the appointment power from Congress under the Articles to the President under the Constitution. $^{23}$

The notes from the Constitutional Convention record what the Framers decided when they discussed executive power for one day in May, eight days in June, nine days in July, eleven days in August, and seven days in September of $1787 .{ }^{24}$ In addition, the drafts prepared by the Convention's Committee of Style

15. See, e.g., Zivotofsky ex rel. Zivotofsky v. Kerry, 135 S. Ct. 2076, 2104 (2015) (Thomas, J., concurring in part and dissenting in part); see also Myers v. United States, 272 U.S. 52, 204 (1926) (McReynolds, J., dissenting) (citing the Articles of Confederation).

16. See, e.g., Weiss v. United States, 510 U.S. 163, 184 (1994) (Souter, J., concurring); United States v. Curtiss-Wright Exp. Corp., 299 U.S. 304, 317 (1936).

17. See, e.g., N.L.R.B. v. SW Gen., Inc., 137 S. Ct. 929, 935 (2017); Hamdan v. Rumsfeld, 548 U.S. 557, 691 (2006) (Thomas, J., dissenting).

18. See, e.g., Nixon v. Fitzgerald, 457 U.S. 731, 774 (1982) (White, J., dissenting); Weiss v. United States, 510 U.S. 163, 186 n.1 (1994) (Souter, J., concurring).

19. See, e.g., N.L.R.B. v. Noel Canning, 134 S. Ct. 2550, 2570 (2014); Nixon v. Adm'r of Gen. Servs., 433 U.S. 425, 510 (1977) (Burger, C.J., dissenting).

20. See, e.g., N.L.R.B. v. Sw. Gen., Inc., 137 S. Ct. 929, 946 (2017); Zivotofsky, 135 S. Ct. at 2104 (Thomas, J., concurring in part and dissenting in part).

21. See MASs. Const. pt. I, ch. II, $\$ 1$, art. VII (1780).

22. See generally Gregory E. Maggs, A Concise Guide to the Articles of Confederation as a Source for Determining the Original Meaning of the Constitution, 84 GEO. WASH. L. REV. 397 (2017) (explaining how the Articles provide evidence of the Constitution's original meaning).

23. See Freytag v. Comm'r., 501 U.S. 868, 904 n.4 (Scalia, J., concurring in part and concurring in judgment).

24. See 1 The Records of the Federal Convention of 1787, at 21 (Max Farrand ed., 1911) [hereinafter FARRAND'S RECORDS] (May 29); id. at 63, 64, 66, 68, 7o (June 1); id. at 74, 8o, $81,88,90$ (June 2); id. at 96, 109, 113 (June 4); id. at 116, 119 (June 5); id. at 175 (June 9); $i d$. at 224,236 (June 13); id. at 244 (June 15); id. at 292, 300 (June 18); 2 FARRAND's RECORDS 29 (July 17); id. at 41 (July 18); id. at 52, 57 (July 19); id. at 61-63 (July 20); id. at 73, 80 (July 21); id. at 95 (July 23); id. at 99, 102 (July 24); id. at 109 (July 25); id. at 116, 118, 
and Committee of Detail reveal choices made in drafting Article II. ${ }^{25}$ In Myers $v$. United States, the Court looked carefully at the debates in the Convention before ruling on whether Congress could limit the President's removal power. ${ }^{26}$

Arguing for ratification of the Constitution in 1788, James Madison addressed the President's powers in Federalist No. 42, John Jay discussed them in No. 64, and Alexander Hamilton considered them in Federalist Nos. 67-75. ${ }^{27}$ Participants at the state ratifying conventions also made important comments about executive power. ${ }^{28}$ The Supreme Court has examined the Virginia ratification debates when construing the President's treaty power in Reid v. Covert. ${ }^{29}$

Early presidential practice under the Constitution can provide clues about the original meaning of Article II based on the assumption that early presidents knew and followed the original meaning. For example, in United States $v$. Curtiss-Wright Export Corp., the Court observed that President Washington had asserted what would now be called the "executive privilege" in refusing to discuss diplomatic negotiations. ${ }^{30}$ And dictionaries from the Founding Era can provide evidence of the original objective meaning of key words in Article II. ${ }^{31}$ For example, Justice Scalia looked up the meaning of "inferiour" in Samuel Johnson's eighteenth-century dictionary when determining the meaning of "inferior officer" in Morrison v. Olson. ${ }^{32}$

121 (July 26); id. at 185-186 (Aug. 6); id. at 196 (Aug. 7); id. at 297 (Aug. 15); id. at 319 (Aug. 17); id. at 328 (Aug. 18); id. at 335, 342 (Aug. 20); id. at 367 (Aug. 22); id. at 389, 395 (Aug. 23); id. at 401, 404, 405 (Aug. 24); id. at 411, 418, 419, 420 (Aug. 25); id. at 426, 427 (Aug. 27); id. at 494, 495, 497, 499 (Sept. 4); id. at 511 (Sept. 5); id. at 521 (Sept. 6); id. at $535,538,541$ (Sept. 7); id. at 547, 553 (Sept. 8); id. at 564 (Sept. 10); id. at 626-27, 636, 63839 (Sept. 15). See generally Philip B. KuRLAND \& RAlPH LeRner, THe Founder's ConstiTUTION $\mathbb{S}$ 2.2.1-3, 2.3 (2001) (identifying these excerpts from the records of the Constitutional Convention).

25. See id. at 2 FARRAND's RECORDS 132, 134-136, 143, 145, 146, 155, 157, 158, 169, 171, 172 (Committee of Detail); id. at 572-575, 598-600 (Committee of Style).

26. 272 U.S. 52, 110 (1926).

27. For background concerning the Federalist Papers, see Gregory E. Maggs, A Concise Guide to the Federalist Papers as a Source of the Original Meaning of the United States Constitution, 87 B.U. L. REV. 801 (2007).

28. For background concerning the state ratification debates, see Gregory E. Maggs, A Concise Guide to the Records of the State Ratifying Conventions as a Source of the Original Meaning of the United States Constitution, 2009 U. ILL. L. REV. 457.

29. 354 U.S. $1,15 \&$ n.32 (1957) (stating that the Treaty Power does not permit the "prohibitions of the Constitution ... [to] be nullified by the Executive or by the Executive and the Senate combined").

30. 299 U.S. 304, 320 (1936).

31. See Gregory E. Maggs, A Concise Guide to Using Dictionaries from the Founding Era To Determine the Original Meaning of the Constitution, 82 GEO. WASH. L. REV. 358 (2014).

32. 487 U.S. 654,719 (1988) (Scalia, J., dissenting). 
HOW JUSTICE THOMAS DETERMINES THE ORIGINAL MEANING OF ARTICLE II OF THE CONSTITUTION

\section{THREE OBSERVATIONS REGARDING HOW JUSTICE THOMAS DETERMINES THE ORIGINAL MEANING OF ARTICLE II'S PROVISIONS}

Although known for his usual silence during oral argument, Justice Thomas is the most prolific writer of the current members of the Supreme Court. Last year, for example, Justice Thomas wrote almost twice as many opinions as any of his colleagues. ${ }^{33}$ His extensive collection of utterances on Article II facilitates an evaluation of his methodology. My three observations are (1) that Justice Thomas has a greater inclination to theorize about the nature of executive power under Article II than about other features of the Constitution; (2) that he relies on all of the most commonly cited historical sources when discerning the original meaning of the Constitution; and (3) that he looks primarily for the original objective meaning of Article II, rather than some other type of original meaning (such as the original intent of the Framers or the original understanding of the participants at the state ratification conventions).

\section{A. Observation No. 1: A Greater Inclination to Theorize}

Justice Thomas seems much more inclined to theorize about executive power than other aspects of constitutional law. As explained above, Justice Thomas usually focuses on specific questions about the meaning of individual words in the Constitution. He typically finds answers in dictionaries from the Founding Era and similar sources, and tends to eschew abstract constitutional arguments. But when interpreting Article II, he tends to move beyond the text and into the realm of theory.

For example, in Hamdan $v$. Rumsfeld, ${ }^{34}$ Justice Thomas made the nature of executive power the focus of his dissent. That case concluded that the President alone could not decide whether to detain a U.S. citizen captured on the battlefield while fighting for the enemy. In his analysis, Justice Thomas did not just look at the words of Article II, but instead considered principles of constitutional competence and authority. In his dissent, he wrote: "The plurality's evident belief that it is qualified to pass on the 'military necessity' ... of the Commander in Chief's decision to employ a particular form of force against our enemies is so antithetical to our constitutional structure that it simply can-

33. See The Statistics, 130 Harv. L. ReV. 507, 507 (2016) (indicating that Justice Thomas wrote thirty-nine opinions, while Justice Alito, the next most prolific author, wrote twenty).

34. 548 U.S. 557 (2006). 
not go unanswered." ${ }^{35}$ His conclusions about the residual foreign affairs powers in Zivotofsky $v$. Kerry ${ }^{36}$ are similarly broader than simply looking at the meaning of individual constitutional terms. In deciding that the President rather than Congress could determine the wording of U.S. passports, Justice Thomas reasoned that "the President is not confined to those powers expressly identified in [the Constitution]." 37

I see two possible explanations for this departure from Justice Thomas's usual practice of seeing a horse but not seeing horseness. The first explanation is that Justice Thomas has concluded that Article I limits legislative power in a way that Article II does not limit executive power. The first sentence of Article I says that "[a]ll legislative Powers herein granted shall be vested in a Congress of the United States ...." ${ }^{38}$ In contrast, the first sentence of Article II contains no "herein granted" limitation; it says that " $[t]$ he executive Power shall be vested in a President of the United States of America." ${ }^{39}$ In Zivotofsky, Justice Thomas explained that this distinction implies that the President has powers not enumerated in Article II: "By omitting the words 'herein granted' in Article II, the Constitution indicates that the 'executive Power' vested in the President is not confined to those powers expressly identified in the document. Instead, it includes all powers originally understood as falling within the 'executive Power' of the Federal Government." 40

Because Justice Thomas has this understanding, his interpretation of Article II is necessarily less textual than his interpretation of Article I. He must be less concerned with the historical meaning of specific words, and more concerned with other kinds of arguments about what powers the Constitution originally assigned the President. In Zivotofsky, for example, he looked for evidence of the public "understanding of executive power [that] prevailed in America" during the Founding Era. ${ }^{41}$

A second explanation is that deciding Article II issues without resorting to theory is difficult due to the brevity of Article II's text and the fact that many of its phrases appear to be terms of art. The President's powers are given in the 320 words of Article II, Sections 2 and 3 . In contrast, Congress's powers are detailed in the 684 words of Article I, Sections 8 and 9. Even putting aside possible implications from the omission of the "herein granted" language, Article II

\footnotetext{
35. Id. at 678 (Thomas J., dissenting).

36. 135 S. Ct. 2076, 2096 (2015) (Thomas, J., dissenting).

37. Id. at 2098.

38. U.S. CONST. art. I, $\mathbb{1}_{1}$ (emphasis added).

39. U.S. CONST. art. II, $\mathbb{S} 1$.

40. Zivotofsky, 135 S. Ct. at 2098.

41. Id.
} 
simply contains much less detail. In addition, Article II uses compound phrases, such as "Commander in Chief" and "officer of the United States," which would seem to have special meanings that would not appear in dictionaries. ${ }^{42}$ Narrow textual analysis, accordingly, may seem insufficient to resolve issues arising under Article II.

\section{B. Observation No. 2: Reliance on Many Sources of Original Meaning}

Justice Thomas routinely cites all seven of the key sources of original meaning that I have mentioned in his decisions on executive power. This observation may have practical significance for Supreme Court litigation. Parties who wish to persuade Justice Thomas in Article II cases should seek support in all of these sources. Though a full description of each of Justice Thomas's majority, concurring, and dissenting opinions is beyond the scope of this Essay, an example of his reliance on each source will demonstrate the point.

In his recent opinion concurring in the judgment in Perez v. Mortgage Bankers Association, Justice Thomas relied on early state constitutions and the Records of the Federal Convention to determine the executive power to create binding interpretations of administratively promulgated regulations. ${ }^{43}$ The majority opinion in Perez had merely considered a question under the Administrative Procedure Act: whether an agency's substantial revision of its interpretation of a regulation should be construed as an amendment of the regulation. ${ }^{44}$ Justice Thomas, however, thought it necessary to address larger questions of executive power and how the Framers were concerned about the weakness of separation of powers under state constitutions. ${ }^{45}$

Justice Thomas relied on the Articles of Confederation in Zivotofsky v. Ker$r y .{ }^{46}$ In that case, the Court considered a federal statute that concerned persons born in Jerusalem. The statute required the State Department, upon request, to list the place of birth on the person's passport as "Jerusalem, Israel" as opposed to just "Jerusalem." The majority held that the statute violated the separation of powers because it interfered with the President's exclusive power of diplomatic

42. See, e.g., Jennifer L. Mascott, Who Are "Officers of the United States"?, 70 STAN. L. REV. (forthcoming 2018), http://papers.ssrn.com/abstract=2918952 [http://perma.cc/P3Z6-GPLP] (discussing the original meaning of "Officers of the United States").

43. 135 S. Ct. 1199, 1216 (2015) (Thomas, J., concurring in judgment).

44. Id. at 1203 (majority opinion).

45. See id. at 1214 (Thomas, J., concurring in the judgment).

46. 135 S. Ct. at 2076. 
recognition. ${ }^{47}$ Justice Thomas concurred in part and dissented in part. He concluded that residual foreign affairs powers were vested in the President rather than in Congress, comparing the Articles of Confederation to the Constitution. ${ }^{48}$

Justice Thomas relied heavily on the Federalist Papers in his dissents in Hamdi v. Rumsfeld ${ }^{49}$ and Hamdan v. Rumsfeld. ${ }^{50}$ In Hamdi, the question was whether the President could conclusively decide who was an enemy combatant subject to detention for the duration of a conflict. ${ }^{51}$ In Hamdan, the principal question was whether the President could establish military tribunals to try detained enemy combatants for conspiracy to commit war crimes. ${ }^{52}$ In both cases, Justice Thomas saw support in the Federalist Papers for the proposition that the President had the primary responsibility to protect national security. ${ }^{53}$

Justice Thomas cited the Virginia state ratification debates in his opinion concurring in the judgment in Bond $v$. United States. ${ }^{54}$ The case concerned the power of the President, with the consent of the Senate, to make treaties that would give the government additional powers beyond those enumerated in $\mathrm{Ar}$ ticle I, Section $8 .^{55}$ In concluding that the President lacked this power, Justice Thomas cited both early presidential practice ${ }^{56}$ and four dictionaries from the Founding Era. ${ }^{57}$

Reliance on these sources of the original meaning is not merely a matter of preference when writing his own opinions. Justice Thomas joins the opinions of other Justices that cite these sources but typically declines to join the ones that do not. One example is NLRB $v$. Noel Canning, which concerned recess appointments. ${ }^{58}$ In that case, Justice Scalia wrote an opinion concurring in the judgment in which he cited various sources of the original meaning of the term "recess." 59 Justice Thomas joined this opinion. ${ }^{60}$ But Justice Thomas pointedly

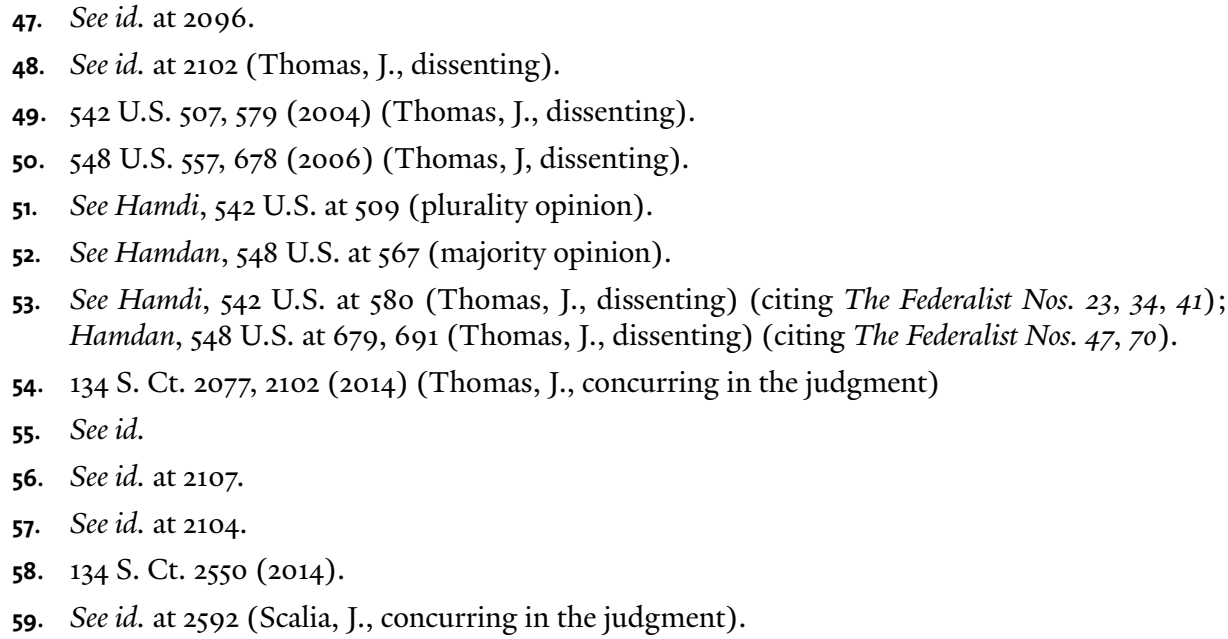


refused to join the entirety of the majority in Bank Markazi v. Peterson. ${ }^{61}$ In that case, the Court held that the Iran Threat Reduction Act of 2012 did not violate the separation of powers. Justice Thomas refused to join only Part II-C of the Court's opinion, which spoke eloquently about executive determinations of foreign sovereign immunity. ${ }^{62}$ But because it did not cite any of the sources of original meaning that Justice Thomas typically relies on, he did not agree with the arguments.

This observation might be more interesting and possibly more useful if a review of the cases showed that Justice Thomas favored some sources more than others. Such a discovery might yield further insight into Justice Thomas's views about the President's powers or suggest what litigants should emphasize when trying to persuade Justice Thomas. But I could discern no such evidence. Justice Thomas considers all of the leading sources relevant and apparently has not weighted any of them more or less heavily.

\section{Observation No. 3: Search for the Original Objective Meaning}

In deciding questions under Article II, Justice Thomas adheres to his general approach of seeking the original objective meaning. For example, as noted above, Justice Thomas in Zivotofsky announced that he was looking for the "understanding of executive power [that] prevailed in America" in the Founding Era, rather than looking for the original intent of the Framers or original understanding of the participants at the state ratifying conventions. But Justice Thomas has not looked exclusively at the sources, like dictionaries, that best reveal that meaning. Instead, he confirms the original objective meaning by looking at other sources of the original meaning. Again, Bond v. United States presents an indicative example. ${ }^{63}$ In Bond, he cited both evidence of the original understanding as shown by the records of the ratification debates and the objective meaning shown in dictionaries. Litigants before the Court therefore should not overlook evidence that might bolster arguments that focus specifically on the original objective meaning of the Constitution.
6o. See id.
61. 136 S. Ct. 1310 (2016).
62. See id. at $1316 \mathrm{n}$. .
63. 134 S. Ct. 2077, 2102 (Thomas, J., dissenting). 


\section{CONCLUSION}

Justice Thomas's approach to executive power appears to be consistent with his general practice of looking for evidence of the original public meaning of constitutional terms and confirming that meaning with all pertinent historical sources. The practical conclusions from my observations are twofold. First, a litigator who hopes to persuade Justice Thomas in an Article II case should attempt to find support in all seven of the historical sources discussed above. Second, the same litigator also should consider making arguments based on theories of executive power - such as those concerning the competence and authority of the President compared to Congress and the Courts-even though Justice Thomas generally decides other kinds of constitutional questions with a focus more on the text of the Constitution than on abstract principles.

Gregory Maggs is a Professor of Law at The George Washington University Law School. This paper was presented at a panel on Justice Thomas and Article II at the Yale Federalist Society's conference, "Celebrating Justice Thomas: 25 Years on the Supreme Court." I was a law clerk for Justice Thomas during the Supreme Court October Term 1991. My conclusions in this paper are based on my reading of Justice Thomas's published opinions and not on any non-public information. I am very grateful to the Yale Federalist Society for hosting the conference and inviting me to participate.

Preferred Citation: Gregory E. Maggs, How Justice Thomas Determines the Original Meaning of Article II of the Constitution, 127 YALE L.J. F. 210 (2017), http:// www.yalelawjournal.org/forum/how-justice-thomas-determines-the-original -meaning-of-article-ii-of-the-constitution. 